\title{
ANALISIS KINERJA KEUANGAN \\ PEMERINTAH PROVINSI KALIMANTAN TIMUR
}

\author{
Agus Tri Sulistyo \\ Direktorat Pembinaan Pengelolaan Keuangan Badan Layanan Umum
}

Alamat Korespondensi: agustrisulistyo@gmail.com

\section{INFORMASI ARTIKEL}

Diterima Pertama

9 Oktober 2017

Dinyatakan Diterima

28 Maret 2018

KATA KUNCI:

The Level of Regional Financial Independence, PAD, Strategy for Improve Financial Performance, Otonomi, Fiscal Stress,

KLASIFIKASI JEL:

H11

\begin{abstract}
ABSTRAK
Regional finance is an integral part of the state's finance in the allocation of economic resources, equitable development and the creation of economic, social and political stability. The role of regional finances are becoming more important, because of the limited funds that can be transferred to the local government in form of subsidies and support. Other than that, because of the increased of local problem's complexity faced by local authority, the solutions require active participation from the people in the region. This study aims to analyze the level of local financial autonomy, by measuring the performance of local financial management, by using the ratio of local financial autonomy, the ratio of financial ability, and the ratio of PAD effectiveness and formulate strategies to find solutions, and to improve financial performance. The results of financial performance analysis of East Kalimantan Province showed good results if it being viewed from the level of independence, level of ability, and level of effectiveness. Further analysis results shows that PAD has a positive and significant effect on financial performance. While DAPER, PMA $P M D N$ have no effect. Based on AHP results, the strategy priority that should be done is to do service innovations.
\end{abstract}

Keuangan daerah merupakan bagian tak terpisahkan dari keuangan negara dalam pengalokasian sumber-sumber ekonomi, pemerataan pembangunan, serta menciptakan stabilitas ekonomi, sosial, dan politik. Peranan keuangan daerah menjadi semakin penting karena adanya keterbatasan dana yang dapat dialihkan ke Pemerintah daerah dalam bentuk subsidi dan bantuan. Selain itu, juga karena semakin kompleksnya persoalan yang dihadapi daerah, yang pemecahannya membutuhkan partisipasi aktif dari masyarakat di daerah. Penelitian ini bertujuan untuk menganalisis tingkat kemandirian keuangan daerah dengan mengukur kinerja pengelolaan keuangan daerah dengan menggunakan rasio kemandirian keuangan daerah, rasio kemampuan keuangan dan rasio efektivitas PAD selama periode 2009-2016, serta merumuskan strategi untuk menemukan solusi dan memperbaiki kinerja keuangan. Hasil analisis kinerja keuangan Provinsi Kalimantan Timur menunjukkan hasil yang baik bila dilihat dari tingkat independensi, tingkat kemampuan, dan tingkat efektivitas. Hasil analisis lebih lanjut menunjukkan bahwa PAD memiliki pengaruh positif dan signifikan terhadap kinerja keuangan. Sementara DAPER, PMA, dan PMDN tidak berpengaruh. Berdasarkan hasil AHP diperoleh strategi prioritas yang harus dilakukan adalah melakukan inovasi layanan. 


\section{PENDAHULUAN}

\subsection{Latar Belakang}

Dalam rangka pelaksanaan otonomi daerah dan desentralisasi fiskal, pemerintah daerah dituntut untuk memiliki kemandirian keuangan daerah. Dengan adanya kemandirian keuangan, pemerintah daerah dapat mengurangi ketergantungannya pada bantuan dari pemerintah pusat dan provinsi melalui dana perimbangan. Namun jika keuangan daerah sudah sangat mandiri, bukan berarti daerah sudah tidak perlu mendapatkan dana perimbangan. Dana perimbangan masih tetap diperlukan untuk mempercepat pembangunan di daerah.

Otonomi daerah menghendaki dua aspek kinerja keuangan yang lebih baik. Aspek pertama yakni terkait desentralisasi fiscal, bahwa daerah diberi kewenangan mengurus pembiayaan daerah dengan kekuatan utama pada kemampuan Pendapatan Asli Daerah (PAD). Aspek kedua yaitu terkait manajemen pengeluaran daerah, bahwa pengelolaan keuangan daerah harus lebih akuntabel dan transparan yang menuntut daerah agar lebih efisien dan efektif dalam pengeluaran daerah. Pengelolaan keuangan daerah yang dilakukan secara ekonomis, efisien, dan efektif atau memenuhi prinsip value for money serta partisipatif, transparansi, akuntabilitas, dan keadilan akan dapat mendorong pertumbuhan ekonomi serta kemandirian suatu daerah.

Daerah yang kinerja keuangannya dinyatakan baik berarti daerah tersebut memiliki kemampuan keuangan untuk membiayai pelaksanaan otonomi daerah. APBD pada hakekatnya merupakan salah satu instrumen kebijakan yang dipakai sebagai alat untuk meningkatkan pelayanan umum dan kesejahteraan masyarakat di daerah sesuai dengan tujuan otonomi daerah. APBD memiliki peran penting sebagai alat stabilisasi, distribusi, alokasi sumber daya publik, perencanaan dan pengendalian organisasi serta penilaian kinerja (Mahmudi, 2010). Penilaian kinerja APBD sangat penting dalam kerangka menuju penguatan otonomi daerah dengan new game dan new rulenya (Mardiasmo, 2002).

Di sebagian besar negara berkembang, termasuk Indonesia, atau dalam skala regional Kalimantan Timur, sektor primer masih menjadi sektor tumpuan dalam pencapaian tingkat PDB/PDRB. Sektor primer, terutama pertambangan, sangat menggantungkan pada ketersediaan SDA yang memang tersedia cukup melimpah. Sektor pertambangan yang merupakan sektor unggulan mampu menopang pertumbuhan perekonomian di wilayah Kalimantan Timur.

Masalah merosotnya harga batu bara bagi pemerintah Provinsi Kalimantan Timur mengakibatkan menurunnya kemampuan pembiayaan pemerintah daerah dalam rangka melaksanakan fungsinya sebagai penyelenggara pembangunan, penyelenggara pemerintah, serta pelayan masyarakat. Padahal, penyelenggaraan kegiatan pemerintahan daerah terus meningkat sehingga biaya yang dibutuhkan juga akan bertambah.

Kinerja keuangan adalah suatu ukuran kinerja yang menggunakan indikator keuangan (Sularso dan Restianto, 2011). Salah satu alat untuk menganalisis kinerja pemerintah daerah dalam mengelola keuangan daerahnya adalah dengan melakukan analisis rasio keuangan terhadap APBD (Halim dan Kusufi, 2012). Analisis rasio keuangan pada APBD dilakukan dengan membandingkan hasil yang dicapai dari satu periode dibandingkan dengan periode sebelumnya sehingga dapat diketahui bagaimana kecenderungan yang terjadi.

Pengelolaan keuangan yang dituangkan dalam APBD mencerminkan kemampuan pemerintah daerah dalam membiayai pelaksanaan tugas-tugas pemerintahan, pembangunan, dan pelayanan sosial masyarakat. APBD merupakan kebijakan yang utama bagi Pemerintah daerah. Sebagai kebijakan, APBD mendukung posisi sentral dalam upaya pengembangan kapabilitas dan efektivitas Pemerintah Daerah. APBD sebagai salah satu instrumen ekonomi dalam keuangan daerah, prosesnya tidak terlepas dari tema desentralisasi ekonomi. Sebagai instrument kebijakan, APBD mendukung posisi sentral dalam upaya pengembangan kapabilitas dan efektivitas Pemerintah Daerah. Oleh karena itu, pengelolaan keuangan daerah sangatlah penting dan perlu mendapat perhatian yang lebih agar sumber daya keuangan dikelola sesuai dengan prinsip ekonomis, efisien, efektif, dan dapat dipertanggungjawabkan.

Tabel 1. Pendapatan APBD Kalimantan Timur Tahun 2013-2016 (milyar Rp)

\begin{tabular}{llrrrc}
\hline No & Tahun & $\mathbf{2 0 1 3}$ & $\mathbf{2 0 1 4}$ & $\mathbf{2 0 1 5}$ & $\mathbf{2 0 1 6}$ \\
\hline 1. & Pendapatan & 11.631 & 11.258 & 9.456 & 7.987 \\
2. & PAD & 5.885 & 6.663 & 4.951 & 4.031 \\
3. & Dana & 5.335 & 4.253 & 4.024 & 3.941 \\
& Transfer & &
\end{tabular}

Sumber : BPKAD Provinsi Kalimantan Timur (data diolah, 2017)

Tabel 1 menggambarkan bahwa pendapatan pada APBD tahun anggaran 2015 di Kalimantan Timur mengalami penurunan dibandingkan APBD tahun anggaran sebelumnya. Penurunan pendapatan tersebut disebabkan oleh berkurangnya Pendapatan Asli Daerah dan Dana Transfer. Dana Transfer merupakan dana dari Pemerintah Pusat yang berupa Dana Bagi Hasil (DBH), Dana Alokasi Umum (DAU), dan Dana Alokasi Khusus (DAK).

Dalam pelaksanaan otonomi daerah dan desentralisasi fiskal, kinerja pemerintah sangat penting untuk dilihat dan diukur. Keberhasilan 
suatu pemerintahan di era otonomi daerah dapat dilihat dari berbagai ukuran kinerja yang telah dicapai. Salah satu bentuknya adalah kinerja anggaran. Anggaran merupakan komponen penting yang menjadi perhatian publik karena memiliki peran penting sebagai alat stabilisasi, distribusi, alokasi sumber daya publik, perencanaan, dan pengendalian organisasi, serta penilaian kinerja (Mahmudi, 2006). Penilaian kinerja APBD sangat penting dalam kerangka menuju penguatan otonomi daerah dengan new game dan new rulenya (Mardiasmo, 2002).

Analisis rasio keuangan telah banyak digunakan oleh sektor swasta, sedangkan pada lembaga publik penggunaannya masih terbatas. Padahal dari hasil analisis dapat diketahui tingkat kinerja pemerintah daerah dan hasil analisis tersebut diharapkan dapat dijadikan suatu acuan untuk meningkatkan kinerjanya dari tahun ke tahun. Pengukuran kinerja keuangan daerah sangat penting untuk menilai transparansi dan akuntabilitas/ pertanggungjawaban laporan realisasi anggaran pemerintah daerah dalam melakukan pengelolaan keuangan daerah. Salah satu alat untuk menganalisis kinerja Pemerintah Daerah dalam mengelola keuangan daerahnya adalah dengan melakukan analisis rasio keuangan terhadap APBD (Halim dan Kusufi, 2012). Analisis rasio keuangan pada APBD dilakukan dengan membandingkan hasil yang dicapai dari satu periode dibandingkan dengan periode sebelumnya sehingga dapat diketahui bagaimana kecenderungan yang terjadi.

\subsection{Tinjauan Penelitian Terdahulu}

Susantih dan Saftiana (2009) pada penelitiannya yang berjudul "Perbandingan Indikator Kinerja Keuangan Pemerintah Provinsi Se-Sumatera Bagian Selatan" menggunakan indikator penelitian berupa kemandirian, efektivitas, dan aktivitas keuangan daerah pada lima provinsi se-Sumatera bagian selatan. Hasil analisis menunjukkan bahwa kinerja keuangan daerah Provinsi Lampung memiliki peringkat tertinggi yaitu $63,81 \%$ dan Provinsi Bengkulu memiliki peringkat terendah, yaitu $49,22 \%$. Hasil analisis kemandirian menunjukkan bahwa Provinsi Lampung memiliki peringkat tertinggi yaitu $50,11 \%$. Begitu juga dengan analisis efektivitas keuangan daerah Provinsi Lampung, yang berada di peringkat tertinggi yaitu $132,17 \%$. Hasil analisis aktivitas keuangan daerah berdasarkan keserasian keuangan daerah menunjukkan bahwa Provinsi Sumatera Selatan memiliki nilai rasio belanja aparatur daerah terendah yaitu 32,43\% dan nilai rasio pelayanan publik tertinggi yaitu 40,52\%. Sementara itu, hasil analisis uji beda Kolmogorov Smirnov Test menunjukkan secara rata-rata nilai asymp sig sebesar 0,859. Hal ini berarti bahwa tidak ada perbedaan yang signifikan pada kinerja keuangan pemerintah daerah pada lima provinsi se-Sumatera bagian selatan.

Penelitian Haryadi (2002) menunjukkan fiscal stress (tekanan keuangan) secara signifikan berpengaruh terhadap kinerja keuangan Pemerintah Kabupaten/Kota di Jawa Timur sebelum dan sesudah krisis ekonomi. Hasil dari penelitian tersebut adalah tingkat kemampuan pembiayaan daerah sebelum krisis relatif lebih besar dibandingkan sesudah krisis. Dari segi kemampuan mobilisasi, daerah relatif lebih baik sesudah krisis, sedangkan dari segi tingkat ketergantungan secara relatif menunjukkan perkembangan yang positif sesudah krisis.

Penelitian lain dilakukan oleh Andayani (2004). Hasil dari penelitian ini menunjukkan bahwa terjadi perubahan rata-rata pendapatan dan belanja daerah kabupaten/kota sebelum dan sesudah adanya krisis. Pada masa krisis ekonomi, rata-rata pendapatan dan belanja daerah kabupaten/kota mengalami penurunan yang signifikan. Penerimaan daerah yang tidak stabil selama krisis ekonomi menyebabkan adanya kondisi fiscal stress, sehingga terjadi penurunan rata-rata pendapatan dan belanja daerah.

\subsection{Tujuan Penelitian}

Berdasarkan latar belakang dan penelitian terdahulu, tujuan yang ingin dicapai dalam penelitian ini adalah merumuskan strategi peningkatan kinerja keuangan Pemerintah Provinsi Kalimantan Timur.

\section{KERANGKA TEORI}

\subsection{Keuangan Daerah}

Keuangan daerah mempunyai arti yang sangat penting dalam rangka pelaksanaan Pemerintahan dan kegiatan pembangunan melalui pelayanan kemasyarakatan di daerah. Oleh karena itu, keuangan daerah diupayakan untuk berjalan secara berdaya guna dan berhasil guna. Secara konseptual, munculnya otonomi daerah telah memberikan keleluasaan kepada daerah untuk mengatur dan mengurus sumber-sumber penerimaan daerah yang berasal dari Pendapatan Asli Daerah, Dana Perimbangan, Pinjaman Daerah dan sumber-sumber penerimaan lainnya.

\subsection{Kinerja Keuangan Daerah}

Kinerja merupakan pencapaian atas apa yang direncanakan, baik oleh individu maupun organisasi. Secara sederhana, kinerja seseorang atau organisasi dikatakan baik apabila hasil yang dicapai sesuai dengan target yang direncanakan. Apabila pencapaian melebihi target, maka kinerja dikatakan sangat baik, sedangkan apabila lebih rendah dari target maka dapat dikatakan bahwa kinerjanya buruk. 
Analisis kinerja keuangan pada dasarnya dilakukan untuk menilai kinerja di masa lalu dengan melakukan berbagai analisis sehingga diperoleh posisi keuangan yang mewakili realitas entitas dan potensi-potensi kinerja yang akan berlanjut. Salah satu alat analisis kinerja pemerintah daerah dalam mengelola keuangan daerahnya adalah dengan melakukan analisis rasio keuangan terhadap APBD yang telah ditetapkan dan dilaksanakannya. Beberapa rasio keuangan yang dapat digunakan untuk mengukur akuntabilitas pemerintah daerah yaitu rasio kemandirian, rasio kemampuan, dan rasio efektivitas PAD (Halim, 2007).

Penilaian kinerja keuangan daerah bertujuan agar para pengelola keuangan tidak semena-mena membelanjakan uangnya, tetapi menjadi lebih fokus terhadap target-target kinerja yang harus dicapai. Pengukuran kinerja juga dapat dimanfaatkan untuk melihat ada tidaknya penyimpangan antara kinerja aktual dengan kinerja yang diharapkan.

\subsection{Rasio Kemandirian Keuangan Daerah}

Rasio kemandirian digunakan untuk menunjukkan kemampuan pemerintah daerah dalam membiayai sendiri kegiatan pemerintahan, pembangunan, dan pelayanan kepada masyarakat yang telah membayar pajak dan retribusi sebagai sumber pendapatan yang diperlukan daerah. Kemandirian keuangan daerah ditunjukkan oleh besar kecilnya pendapatan asli daerah dibandingkan dengan pendapatan daerah yang berasal dari sumber yang lain, misalnya bantuan pemerintah pusat ataupun dari pinjaman (Halim, 2007).

Rasio Kemandirian $=\frac{\text { Pendapatan Asli Daerah }(P A D)}{\text { TransferPusat }+ \text { Pinjaman }} \times 100 \%$

Pola hubungan antara Pemerintah pusat dengan daerah lebih kepada bentuk pemberian dukungan dan pengarahan, di mana tata hubungan tersebut sebenarnya bersifat gradatif antara pengarahan yang dilakukan dengan tingkat kemandirian daerah.

Adapun pola hubungan dimaksud, dapat dirinci sebagai berikut:

1. Pola Tata Hubungan Instruktif: pengarahan lebih banyak dilakukan pemerintah pusat;

2. Pola Tata Hubungan Konsultatif: pengarahan (campur tangan) pemerintah pusat mulai berkurang karena kemampuan daerah sudah mulai meningkat;

3. Pola Tata Hubungan Partisipatif: pengarahan pemerintah pusat berkurang lebih banyak lagi karena kemandirian daerah sudah cukup tinggi;

4. Pola Tata Hubungan Delegatif: pemerintah pusat sudah jauh mengurangi atau bahkan meniadakan campur tangannya dalam urusan otonomi daerah.
Tabel 2. Pola Hubungan Tingkat Kemandirian Keuangan Daerah

\begin{tabular}{ccc}
\hline $\begin{array}{c}\text { Kemampuan } \\
\text { Keuangan }\end{array}$ & $\begin{array}{c}\text { Rasio Kemandirian } \\
(\%)\end{array}$ & Pola Hubungan \\
\hline Rendah Sekali & $0-25$ & Instruktif \\
Rendah & $>25-50$ & Konsultatif \\
Sedang & $>50-75$ & Partisipatif \\
Tinggi & $>75-100$ & Delegatif \\
\hline Sumber : Halim, 2007 & &
\end{tabular}

Sumber : Halim, 2007

\subsection{Rasio Kemampuan Keuangan Daerah}

Rasio Kemampuan Keuangan Daerah adalah kemampuan pemerintah daerah dalam rangka meningkatkan Pendapatan Asli Daerah (PAD) guna membiayai pembangunan. Rasio Kemampuan Keuangan Daerah dihitung dengan cara membandingkan antara komponen Pendapatan Asli Daerah (PAD) terhadap Total Pendapatan Daerah (TPD). Rasio ini menunjukkan derajat kontribusi PAD terhadap total penerimaan daerah. Semakin tinggi kontribusi PAD maka semakin tinggi kemampuan Pemerintah daerah dalam menyelenggarakan desentralisasi. Rasio ini dirumuskan sebagai berikut (Mahmudi, 2010):

Rasio Kemampuan $=\frac{\text { Pendapatan Asli Daerah }(P A D)}{\text { Total Pendapatan Daerah }} \times 100 \%$

Kriteria kemampuan keuangan daerah dapat dikategorikan sebagaimana dalam Tabel 3.

Tabel 3. Tingkat Kemampuan Keuangan Daerah

\begin{tabular}{cc}
\hline Rasio Kemandirian $(\%)$ & Kriteria \\
\hline $0-10$ & Sangat Kurang \\
$>10-20$ & Kurang \\
$>20-30$ & Cukup \\
$>30-40$ & Sedang \\
$>40-50$ & Baik \\
$>50$ & Sangat Baik \\
\hline
\end{tabular}

Sumber: Tim Litbang Depdagri - Fisipol UGM, 1991

\subsection{Rasio Efektivitas PAD}

Efektivitas adalah pengukuran keberhasilan dalam pencapaian tujuan-tujuan yang telah ditentukan. Efektivitas digunakan untuk mengukur upaya pungut PAD (tax effort) yang dilakukan oleh pemerintah daerah. Keberhasilan suatu daerah dalam melaksanakan roda pemerintahan, salah satunya bisa diukur dengan efektivitas pelaksanaan anggaran utamanya dalam mencari sumber Pendapatan Asli Daerah (PAD). Hal tersebut bisa diketahui dengan mengukur rasio efektivitas PAD. Rasio ini dirumuskan sebagai berikut (Mahmudi, 2010):

$$
\text { Rasio Ef ektivitas } P A D=\frac{\text { Realisasi } P A D}{\text { Target } P A D} \times 100 \%
$$

Semakin tinggi nilai efektivitas menunjukkan bahwa kemampuan Pemerintah daerah dalam melakukan upaya pungut PAD yang semakin baik, dan sebaliknya. Adapun kriteria untuk menetapkan efektivitas pengelolaan 
keuangan daerah, diukur dengan kriteria penilaian kinerja keuangan seperti dalam Tabel 4 berikut ini:

Tabel 4. Kriteria Efektivitas PAD

\begin{tabular}{cc}
\hline Kinerja Keuangan (\%) & Kriteria \\
\hline$>100$ & Sangat Efektif \\
100 & Efektif \\
$90-99$ & Cukup Efektif \\
$75-89$ & Kurang Efektif \\
$<75$ & Tidak Efektif \\
\hline
\end{tabular}

Sumber: Mahmudi, 2010

\section{METODE PENELITIAN}

\subsection{Metode Pengolahan dan Analisis Data}

Data yang digunakan untuk dianalisis meliputi data primer dan data sekunder yang diperoleh dari pihak-pihak terkait. Teknik pengumpulan data yang dilakukan dalam penelitian ini adalah melalui interview (wawancara) dan kuesioner, yang dilakukan di BPKAD Provinsi Kalimantan Timur.

Analisis data merupakan kegiatan yang dilakukan untuk mengungkapkan makna dari data yang telah diperoleh. Dalam penelitian ini, pertama kali akan dilakukan analisis deskriptif kinerja ekonomi dan kinerja keuangan daerah. Selanjutnya untuk memperkuat analisis tersebut, dilakukan analisis regresi linier berganda untuk faktor yang mempengaruhi kinerja keuangan di Pemerintah Provinsi Kalimantan Timur.

Metode penelitian yang dilakukan dalam tulisan ini adalah metode campuran dengan mengumpulkan data kuantitatif, dan setelah itu mengumpulkan data kualitatif untuk membantu menjelaskan atau mengelaborasi tentang hasil kuantitatif selama periode 2009-2016. Data kuantitatif memberikan gambaran umum tentang permasalahan tentang APBD dan diperlukan untuk menyempurnakan, memperluas, atau menjelaskan gambaran kondisi perekonomian Kalimantan Timur.

Berdasarkan hasil analisis regresi linier berganda, akan diperoleh gambaran pengaruh antara variabel, dalam penelitian ini variabel dependen yang digunakan adalah pertumbuhan ekonomi dan variabel independen terdiri dari Harga Batubara Internasional, APBD, Jumlah Penduduk. Oleh karena itu, alat analisis yang akan digunakan untuk pengolahan data tersebut menggunakan aplikasi Statistical Product and Service Solution (SPSS).

Persamaan model regresi linier berganda dalam penelitian ini adalah model logaritma natural sebagai berikut :

$$
\begin{aligned}
\mathrm{KKD}= & \beta 0+\beta 1 \ln \mathrm{PAD}+\beta 2 \ln \mathrm{DAPER}+\beta 3 \ln \mathrm{PMA}+ \\
& \beta 4 \ln \mathrm{PMDN}+\varepsilon \mathrm{i}
\end{aligned}
$$

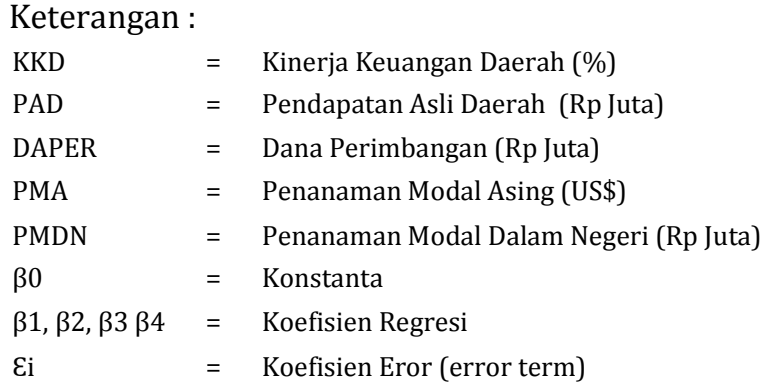

Maka dalam penelitian ini dikemukakan hipotesis sebagai berikut:

H0: Tidak ada peubah bebas yang berpengaruh nyata terhadap kinerja keungan daerah

H1: Minimal ada satu peubah bebas yang berpengaruh nyata terhadap kinerja keuangan daerah

\subsection{Penentuan Strategi}

Analitycal Hierarchy Process (AHP) merupakan suatu analisis yang memungkinkan kita untuk mengambil keputusan yang efektif atas persoalan kompleks dengan jalan menyederhanakan dan mempercepat proses pengambilan keputusan yang alami (Saaty, 1993). Dalam merumuskan strategi kebijakan, kuesioner dan wawancara dilakukan kepada pejabat di BPKAD Provinsi Kalimantan Timur dengan pemilihan sampel secara disengaja karena kepakaran terhadap masalah yang diteliti. Berikut ini adalah beberapa proses yang harus dilakukan dalam analisis dengan AHP, yaitu sebagai berikut (Falatehan, 2016):

1. Identifikasi sistem dilakukan untuk menentukan permasalahan

2. Penyusunan hierarki dilakukan dengan mengabstraksi komponen pada sistem.

3. Penyusunan matriks pendapat individu dan dilakukan melalui perbandingan berpasangan.

4. Penyusunan matriks pendapat gabungan

5. Melakukan sintesis yang digunakan untuk memperoleh perangkat prioritas.

6. Pengukuran konsistensi terhadap pengambilan keputusan. Nilai konsistensi paling tinggi adalah 10 persen.

Prinsip dasar dalam penyusunan strategi ini adalah menyusun hierarki, menentukan prioritas, dan konsistensi logis. Metode Analitycal Hierarchy Process (AHP) dilakukan dengan menggunakan alat bantu software Expert Choice 11.

\section{HASIL DAN PEMBAHASAN}

\subsection{Analisis Kinerja Keuangan}

Analisis terhadap kinerja keuangan Pemerintah Provinsi Kalimantan Timur pada dasarnya dilakukan untuk menilai kinerja keuangan di masa lalu. Dalam penelitian ini kinerja 
keuangan Pemerintah Provinsi Kalimantan Timur diukur dengan menggunakan analisis rasio keuangan daerah sebagai berikut:

\subsubsection{Analisis Rasio Kemandirian Keuangan Daerah}

Kemandirian keuangan Provinsi Kalimantan Timur adalah kemampuan keuangan daerah otonom tersebut dalam mendanai belanja daerahnya dari kemampuan sendiri, yaitu Penghasilan Asli Daerah (PAD). Berdasarkan perhitungan yang telah dilakukan, diperoleh besaran Rasio Kemandirian seperti tampak pada Tabel 5.

Tabel 5. Rasio Kemandirian Keuangan Daerah Pemerintah Provinsi Kalimantan Timur Tahun Anggaran 2009-2016 (Rp juta)

\begin{tabular}{ccccc}
\hline Tahun & PAD & DAPER & $\begin{array}{c}\text { Rasio } \\
(\%)\end{array}$ & $\begin{array}{c}\text { Pola } \\
\text { Hubungan }\end{array}$ \\
\hline 2009 & 2.208 .309 & 3.122 .061 & 70,73 & Partisipatif \\
2010 & 2.711 .300 & 4.308 .464 & 62,93 & Partisipatif \\
2011 & $4.503,239$ & 5.298 .979 & 84,98 & Delegatif \\
2012 & 5.409 .449 & 6.089 .861 & 88,83 & Delegatif \\
2013 & 5.885 .262 & 5.335 .759 & 110,30 & Delegatif \\
2014 & 6.663 .113 & 4.253 .321 & 156,66 & Delegatif \\
2015 & 4.951 .195 & 4.024 .025 & 123,04 & Delegatif \\
2016 & 4.031 .514 & 3.941 .627 & 102,28 & Delegatif \\
$\begin{array}{c}\text { Rata- } \\
\text { rata }\end{array}$ & 4.545 .423 & 4.546 .762 & 99,97 & Delegatif \\
\hline
\end{tabular}

Sumber: BPKAD Provinsi Kalimantan Timur (data diolah tahun 2017)

Rasio kemandirian keuangan daerah di Pemerintah Provinsi Kalimantan Timur mengandung arti bahwa tingkat ketergantungan daerah terhadap Pemerintah Pusat semakin kecil. Rasio tersebut juga menggambarkan tingkat kesejahteraan masyarakat semakin tinggi dengan tingkat partisipasi masyarakat dalam membayar pajak dan retribusi daerah sebagai komponen utama PAD.

\subsubsection{Analisis Rasio Kemampuan Keuangan Daerah}

Salah satu indikator kinerja keuangan daerah dapat dilihat dari besarnya rasio Pendapatan Asli Daerah (PAD) terhadap Total Pendapatan Daerah (TPD). Rasio kemampuan keuangan daerah dihitung berdasarkan perbandingan antara jumlah pendapatan asli daerah dengan total penerimaan daerah. Rasio ini menunjukan kontribusi PAD terhadap pendapatan daerah. Semakin tinggi kontribusi PAD maka semakin tinggi kemampuan pemeritah daerah dalam penyelenggaraan desentralisasi (Halim, 2007). Komponen PAD untuk Pajak Daerah di tingkat provinsi yang terbatas hanya 5 jenis pajak, yaitu: (1) Pajak Kendaraan Bermotor (PKB); (2) Bea Balik Nama Kendaraan Bermotor (BBNKB); (3) Pajak Bahan
Bakar Kendaraan Bermotor (PBBKB); (4) Pajak Air Permukaan; dan (5) Pajak Rokok. Kelima jenis pajak tersebut tiap tahun mengalami fluktuasi dalam pendapatannya, sehingga diperlukan antisipasi dari SKPD yang bertugas memungut pajak tersebut.

Tabel 6. Rasio Kemampuan Keuangan Daerah Pemerintah Provinsi Kalimantan Timur Tahun Anggaran 2009-2016 (juta Rp)

\begin{tabular}{clccc}
\hline Tahun & $\begin{array}{l}\text { Total } \\
\text { PAD }\end{array}$ & $\begin{array}{c}\text { Total } \\
\text { Pendapatan } \\
\text { Daerah }\end{array}$ & $\begin{array}{c}\text { Rasio } \\
(\%)\end{array}$ & $\begin{array}{c}\text { Tingkat } \\
\text { Kemampuan }\end{array}$ \\
\hline 2009 & 2.208 .309 & 5.348 .926 & 41,29 & Baik \\
2010 & 2.711 .300 & 7.041 .040 & 38,51 & Sedang \\
2011 & 4.503 .239 & 9.819 .129 & 45,86 & Baik \\
2012 & 5.409 .449 & 11.904 .245 & 45,44 & Baik \\
2013 & 5.885 .262 & 11.631 .697 & 50,60 & Sangat Baik \\
2014 & 6.663 .113 & 11.285 .828 & 59,04 & Sangat Baik \\
2015 & 4.951 .195 & 9.465 .961 & 52,31 & Sangat Baik \\
2016 & 4.031 .514 & 7.987 .877 & 50,47 & Sangat Baik \\
$\begin{array}{c}\text { Rata- } \\
\text { rata }\end{array}$ & 4.545 .423 & 9.310 .588 & 48,82 & Baik \\
\hline Sumber: BPKA & & &
\end{tabular}

Sumber: BPKAD Provinsi Kalimantan Timur (data diolah tahun 2017)

Dari hasil analisis rasio kemampuan keuangan daerah, dapat dijelaskan bahwa rata-rata rasio kemampuan keuangan daerah Provinsi Kalimantan Timur selama 8 tahun sebesar $48,82 \%$ yang berada interval $40 \leq 50$ atau mempunyai kemampuan yang baik dalam membiayai pembangunan daerah.

\subsubsection{Analisis Rasio Efektivitas PAD}

Rasio Efektifitas menggambarkan kemampuan pemerintah daerah dalam merealisasikan pendapatan asli daerah yang direncanakan dibandingkan dengan target yang ditetapkan berdasarkan potensi riil daerah (Halim, 2007). Kemampuan daerah dalam menjalankan tugas dikategorikan efektif apabila rasio yang dicapai mencapai minimal sebesar 1 atau maksimal $100 \%$. Namun demikian, semakin tinggi rasio efektivitas menggambarkan kemampuan daerah dalam mewujudkan PAD yang semakin baik.

Rasio Efektivitas PAD yang diperoleh Pemerintah Daerah selama tahun 2009 - 2016 seluruhnya dikategorikan sangat efektif kecuali tahun 2015. Rasio Efektivitas PAD di tahun 2015 mengalami penurunan dikarenakan menurunnya realisasi pada pos PAD, seperti pajak daerah dan hasil pengelolaan kekayaan daerah yang dipisahkan. Rata-rata Rasio Efektivitas PAD 91,52 $\%$, berarti kemampuan daerah dalam menjalankan tugas dikategorikan cukup efektif. Hal ini berarti Pemerintah Provinsi Kalimantan Timur memobilisasi penerimaan PAD sesuai dengan yang ditargetkan. Pemerintah Provinsi Kalimantan Timur juga telah realistis dalam menentukan target 
PAD dengan menurunkan targetnya, setelah melihat perkembangan perekonomian di wilayah.

Tabel 7. Hasil Perhitungan Rasio Efektivitas PAD Pemerintah Provinsi Kaltim Tahun Anggaran 20092016 (juta Rp)

\begin{tabular}{cccrc}
\hline Tahun & $\begin{array}{c}\text { PAD } \\
\text { Target }\end{array}$ & $\begin{array}{c}\text { PAD } \\
\text { Realisasi }\end{array}$ & $\begin{array}{c}\text { Rasio } \\
(\%)\end{array}$ & $\begin{array}{c}\text { Tingkat } \\
\text { Kemampuan }\end{array}$ \\
\hline 2009 & 1.994 .760 & 2.208 .309 & 110,71 & Sangat efektif \\
2010 & 2.280 .359 & 2.711 .300 & 118,90 & Sangat efektif \\
2011 & 3.984 .052 & 4.503 .239 & 113,03 & Sangat efektif \\
2012 & 4.690 .480 & 5.409 .449 & 115,33 & Sangat efektif \\
2013 & 5.543 .617 & 5.885 .262 & 106,16 & Sangat efektif \\
2014 & 5.771 .202 & $6 ., 663.113$ & 115,45 & Sangat efektif \\
2015 & 5.095 .146 & 4.951 .195 & 97,17 & Cukup efektif \\
2016 & 3.921 .365 & 4.031 .514 & 102,81 & Sangat efektif \\
$\begin{array}{c}\text { Rata- } \\
\text { rata }\end{array}$ & 4.160 .122 & 4.545 .423 & 91,52 & Cukup efektif \\
\hline
\end{tabular}

Sumber: BPKAD Provinsi Kalimantan Timur (data diolah tahun 2017)

\subsection{Analisis Regresi}

Kinerja keuangan daerah menunjukkan kapasitas pemerintah daerah dalam membiayai sendiri kegiatan pemerintahan, pembangunan dan pelayanan kepada masyarakat.

Tabel 8. Hasil Estimasi Faktor-Faktor yang Mempengaruhi Kinerja Keuangan Pemerintah

Provinsi Kalimantan Timur 2009 -2016

\begin{tabular}{lcccl}
\hline \hline Variabel & Coefficient & $\begin{array}{l}\text { Std. } \\
\text { Error }\end{array}$ & $\begin{array}{l}\text { t- } \\
\text { Statistic }\end{array}$ & Prob. \\
\hline \hline Constant & $-137,8$ & 100,6 & $-1,37$ & 0,304 \\
LnPAD & 30,325 & 4,482 & 6,77 & $0.021^{*}$ \\
LnDAPER & $-13,538$ & 3,881 & $-3,49$ & 0.073 \\
LnPMA & $-9,230$ & 3,206 & 2,88 & 0.102 \\
LnPMDN & $-3,625$ & 2,323 & $-1,56$ & 0.259 \\
\hline \hline R-Squared. & 0.984 & & \\
Adjusted R-Squared & 0,939 & & \\
Prob. (F- statistic). & $0.041^{*}$ & & \\
F hit & 23,94 & & \\
Keterangan: & & & \\
(*) signifikan pada $\alpha=5 \%$ & &
\end{tabular}

Berdasarkan hasil analisis regresi sebagaimana perhitungan di Tabel 8 , didapat nilai $R$-squared sebesar 0,984 atau $98,4 \%$ yang digunakan untuk menguji godness of fit dari model regresi. Hal ini berarti 98,4\% faktor-faktor yang mempengaruhi kinerja keuangan Pemerintah Provinsi Kalimantan Timur dapat dijelaskan dengan variabel independen, sedangkan sisanya 1,6\% dijelaskan oleh sebab-sebab yang lain. Berdasarkan pada hasil estimasi pada tabel didapat nilai Adjusted R-Squared sebesar 0,939 atau 93,9\%, berarti $93.9 \%$ keragaman variabel mampu dijelaskan oleh model, sisanya 6,1\% dijelaskan oleh variabel lain diluar model.

Hasil pada perhitungan menunjukkan bahwa variabel Pendapatan Asli Daerah (PAD), memiliki pengaruh positif dan signifikan terhadap kinerja keuangan daerah Pemerintah Provinsi
Kalimantan Timur. Dana Perimbangan (DAPER), Penanaman Modal Asing (PMA), Penanaman Modal Dalam Negeri (PMDN) memiliki pengaruh negatif dan tidak signifikan terhadap kinerja keuangan Pemerintah Provinsi Kalimantan Timur. Sehingga diperoleh model sebagai berikut:

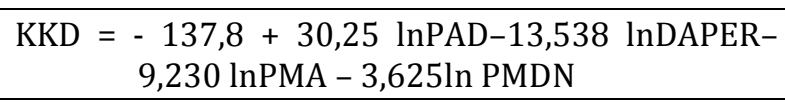

Berdasarkan fungsinya, pendapatan asli daerah (PAD) merupakan aspek penting dalam keberhasilan pelaksanaan otonomi. Jadi, PAD harus menjadi basis utama penerimaan daerah dibandingkan dengan Dana Perimbangan agar daerah mampu melaksanakan otonomi dan desentralisasi seutuhnya tanpa bergantung dari Pemerintah pusat, akan tetapi bukan berarti PAD terutama yang berasal dari pajak dan retribusi daerah harus dipacu setinggi-tinginya. Pemerintah Provinsi Kalimantan Timur harus melaksanakan kebijakan yang mampu memberikan win-win solution bagi masyarakat dan investor yang akan melakukan investasi di Kaltim.

\subsection{AHP (Analithycal Hierarchy Process)}

Perumusan strategi peningkatan kinerja keuangan Pemerintah Provinsi Kalimantan Timur menggunakan metode Analytical Hierarchy Process (AHP).

Berdasarkan hasil analisis pada bab sebelumnya, ternyata Harga Energi Batubara dan APBD memiliki pengaruh nyata dalam pertumbuhan ekonomi di Provinsi Kalimantan Timur sehingga dibutuhkan usaha secara terus menerus untuk menjaga stabilitas ekonomi. Sumber daya alam di Provinsi Kalimantan Timur yang melimpah berupa hasil minyak bumi, gas, batubara dan kayu merupakan salah satu faktor utama dalam membentuk pertumbuhan ekonomi. Sektor pertambangan batubara ternyata merupakan sektor yang harga komoditasnya sangat bergantung dengan kondisi permintaan dan penawaran di pasar. Fluktuasi harga batubara, selain mempengaruhi pertumbuhan ekonomi, ternyata berdampak terhadap APBD Pemerintah Provinsi Kalimantan Timur. Pendapatan daerah berupa PAD dan Dana Perimbangan juga menurun sehingga membuat Pemerintah Provinsi Kalimantan Timur harus menentukan skala prioritas Belanja. PAD yang tidak menentu dari tahun ke tahun akan semakin mempengaruhi beban belanja dalam penyelenggaraan roda pemerintahan daerah, sehingga harus dilakukan suatu upaya dan strategi yang berkesinambungan untuk meningkatkan penerimaan daerah setempat. Dengan demikian upaya dalam rangka mengembangkan potensi penerimaan daerah sangat penting untuk ditingkatkan, yaitu pajak daerah, retribusi daerah, laba perusahaan milik daerah dan lain-lain pendapatan asli daerah yang 
sah.

Dalam metode AHP disusun struktur hierarki yang mencakup level fokus yaitu tujuan yang diharapkan dapat tercapai melalui beberapa alternatif kebijakan yang telah diprioritaskan seperti tampak pada Gambar 1.

Gambar 1. Hierarki Peningkatan Kinerja Keuangan Daerah Pemprov Kalimantan Timur

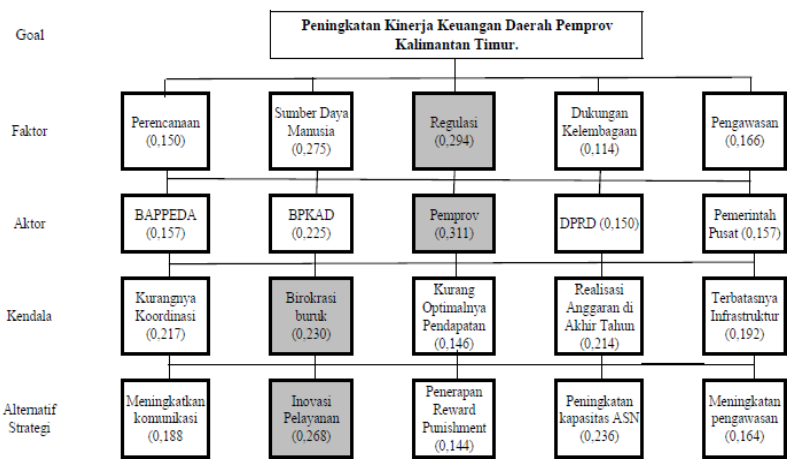

\subsection{Analisis Prioritas Kebijakan}

Dalam pengolahan prioritas kebijakan terbagi menjadi 4 bagian, yaitu faktor, pelaku/aktor, kendala dan alternatif kebijakan/strategi.

\subsubsection{Peranan Faktor dalam Upaya Meningkatkan Kinerja Kemandirian Keuangan Daerah Pemerintah Provinsi Kalimantan Timur}

Perbandingan antar elemen faktor berdasarkan goal meningkatkan kinerja kemandirian keuangan daerah Pemerintah Provinsi Kalimantan Timur, yaitu regulasi dengan nilai 0,294 urutan selanjutnya berturut-turut adalah sumber daya manusia (SDM) dengan nilai 0,275 , pengawasan dengan nilai 0,166 , perencanaan dengan nilai 0,150 dan dukungan kelembagaan dengan nilai 0,114.

Faktor regulasi dengan nilai 0,294 dipilih sebagai proritas utama dibandingkan dengan faktor lainnya dikarenakan regulasi digunakan sebagai dasar pengelolaan keuangan daerah pada pemerintah daerah yang bersangkutan dengan peraturan daerah dan/atau peraturan kepala daerah (Gubernur/Bupati/Walikota) agar dapat dipertanggungjawabkan kepada rakyat sebagai pemberi amanat. Regulasi atau peraturan merupakan hal penting sebagai instrumen untuk membangun kesejahteraan ekonomi dan masyarakat. Tujuan dari regulasi adalah untuk memastikan peraturan yang dibuat telah berjalan dengan efektif dan mewakili kepentingan publik (OECD, 2011). Dengan demikian, regulasi tidak diterbitkan begitu saja, namun perlu dikaji lebih dalam agar berdampak bagi kesejahteraan masyarakat. Regulasi seharusnya mendorong kepada pemenuhan kesejahteraan masyarakat dan dapat mendorong perekonomian ke arah yang lebih baik, jangan sampai regulasi hanya menjadi alat untuk merealisasikan janji-janji politik kepala daerah atau kelompok politik yang berkuasa di sebuah daerah.

Tabel 10. Peranan Faktor dan Bobot Prioritas

\begin{tabular}{|c|l|c|c|}
\hline No & \multicolumn{1}{|c|}{ Faktor } & Nilai & Prioritas \\
\hline 1 & Perencanaan & 0.151 & 4 \\
\hline 2 & SDM & 0.275 & 2 \\
\hline 3 & Regulasi & 0.294 & 1 \\
\hline 4 & Dukungan Kelembagaan & 0.114 & 5 \\
\hline 5 & Pengawasan & 0.166 & 3 \\
\hline
\end{tabular}

\subsubsection{Peranan aktor dalam Upaya Meningkatkan Kinerja Kemandirian Keuangan Daerah Pemerintah Provinsi Kalimantan Timur}

Dalam menentukan alternatif strategi dan keterkaitan antar strategi, diperlukan perbandingan antar unsur "aktor" berdasarkan "faktor" yaitu prioritas pertama Pemerintah Provinsi dengan nilai 0,311. Prioritas kedua adalah BPKAD dengan nilai 0,225. Prioritas ketiga adalah Bappeda dengan nilai 0,157. Prioritas keempat dan kelima secara berturut adalah Pemerintah Pusat dengan nilai 0,157 dan yang terakhir adalah DPRD dengan nilai 0,150 .

Aktor Pemprov dengan nilai 0,311 dinilai memiliki kekuatan dan peluang yang lebih besar dibanding stakeholder lainnya dalam hal penentuan strategi meningkatkan kinerja keuangan Pemerintah Provinsi Kalimantan Timur dengan Gubernur sebagai wakil Pemerintah Pusat di daerah agar pembangunan di daerah berjalan seiring dengan pembangunan pusat. Setiap daerah mempunyai potensi yang berbeda karena perbedaan kondisi ekonomi, sumber daya alam, besaran wilayah, tingkat pengangguran, dan besaran penduduk disinilah peran Pemerintah Provinsi melalui Organisasi Perangkat Daerah (OPD) harus mampu mengelola sumber daya yang ada untuk dikelola secara maksimal sehingga pendapatan daerah dan pendapatan masyarakat akan meningkat.

Tabel 11. Peranan Aktor dan Bobot Prioritas

\begin{tabular}{|c|l|c|c|}
\hline No & \multicolumn{1}{|c|}{ Strategi } & Nilai & Prioritas \\
\hline 1 & Inovasi Pelayanan & 0.268 & 1 \\
\hline 2 & Peningkatan kapasitas ASN & 0.236 & 2 \\
\hline 3 & Peningkatan komunikasi & 0.188 & 3 \\
\hline 4 & Peningkatan pengawasan & 0.164 & 4 \\
\hline 5 & Penerapan reward punishment & 01.44 & 5 \\
\hline
\end{tabular}

4.4.3. Peranan Kendala dalam Upaya Meningkatkan Kinerja Kemandirian Keuangan Daerah Pemerintah Provinsi Kalimantan Timur

Perbandingan antar elemen kendala berdasarkan pelaku yaitu urutan pertama adalah 
buruknya birokrasi nilai 0,230. Kendala selanjutnya yaitu kurangnya koordinasi dengan nilai 0,217 . Urutan ketiga, keempat dan kelima secara berturut-turut adalah berupa realisasi anggaran di akhir tahun dengan nilai 0,214. Terbatasnya infrastruktur dengan nilai 0,192 , dan kurang optimalnya pendapatan dengan nilai 0,146.

Kendala utama yang didapat dari hasil AHP adalah tata kelola birokrasi yang buruk dengan nilai 0,230 . Birokrasi yang buruk ternyata sangat mempengaruhi persepsi masyarakat tentang negara/daerah. Struktur gemuk yang menghabiskan anggaran, hingga maraknya pungli di berbagai sektor pelayanan masih menjadi cermin wajah birokrasi di pemerintahan. Masyarakat melihat dan merasa "negara hadir" jika birokrasi memberikan pelayanan optimal kepada masyarakat. Keadaan yang umum terjadi adalah birokrasi gemuk dan pelayanan yang berbelit-belit tidak hanya mengganggu pemenuhan hak pelayanan publik tetapi juga membebani anggaran Pemerintah. Panjangnya rantai birokrasi dan inefisiensi struktur pemerintah daerah (pemda), masih menjadi pekerjaan rumah bagi Pemerintah. Perampingan birokrasi harus menjadi agenda penting bagi pemda. Miskin struktur dan kaya fungsi merupakan perbaikan yang harus dilakukan oleh pemerintah daerah. Atas layanan birokrat yang panjang dan berbelit-belit wajar bila di kalangan masyarakat muncul olok-olok berupa adagium buruk, "Jika bisa dipersulit, mengapa harus dipermudah?" Dengan dipersulit, mau tidak mau akan diperlukan adanya jasa pelayanan, yang ujungnya uang (pungutan liar).

Tabel 12. Peranan Kendala dan Bobot Prioritas

\begin{tabular}{|c|l|c|c|}
\hline No & Aktor & Nilai & Prioritas \\
\hline 1 & Bappeda & 0.157 & 3 \\
\hline 2 & BPKAD & 0.225 & 2 \\
\hline 3 & Pemprov & 0.311 & 1 \\
\hline 4 & DPRD & 0.150 & 5 \\
\hline 5 & Pusat & 0.157 & 4 \\
\hline
\end{tabular}

\subsubsection{Peranan Strategi dalam Upaya Meningkatkan Kinerja Kemandirian Keuangan Daerah Pemerintah Provinsi Kalimantan Timur}

Dilatarbelakangi oleh UU No. 25 Tahun 2009 tentang Pelayanan Publik, maka sudah menjadi kewajiban bagi organisasi penyelenggara pelayanan publik, yang didalamnya termasuk para pelaksana pelayanan publik untuk bekerja dan bertugas dalam melaksanakan serangkaian tindakan pelayanan publik kepada masyarakat, baik kepada orang perseorangan, kelompok maupun badan hukum yang berkedudukan sebagai penerima manfaat pelayanan publik, baik secara langsung maupun tidak langsung, yang tentunya dengan inovasi pelayanan yang berkualitas, cepat, mudah, terjangkau dan terukur. Hal ini sejalan dengan penelitian dari Jufrizal \& Sujianto (2013), dalam penelitiannya menyimpulkan ada dua strategi yang dapat digunakan dalam peningkatan PAD yaitu strategi inovasi dan strategi peningkatan kualitas.

Inovasi pelayanan merupakan strategi pertama yang harus diterapkan untuk dapat menerapkan strategi-strategi selanjutnya. Inovasi menjadi sesuatu yang mutlak dalam pelayanan publik, sebab apapun kebutuhan masyarakat, pemerintah harus merespon dengan cepat dan tepat. Inovasi juga diharapkan menjadi salah satu cara untuk mendorong percepatan pembangunan secara efektif dan efisien. Inovasi dimaksud bukan hanya berhubungan dengan teknologi dan informasi saja, tetapi juga inovasi dalam peningkatan kualitas SDM, pembuatan standar, serta kerjasama maupun benchmarking dengan institusi lain untuk memberikan perspektif yang berbeda.

Perbandingan antar strategi berdasarkan kendala adalah melakukan inovasi pelayanan sebagai urutan pertama dengan nilai 0,268 . Diikuti secara berturut-turut peningkatan kapasitas ASN $(0,236)$, peningkatan komunikasi $(0,188)$, peningkatan pengawasan $(0,164)$ dan penerapan reward punishment $(0,144)$

Tabel 13. Peranan Strategi dan Bobot Prioritas

\begin{tabular}{|c|l|c|c|}
\hline No & Kendala & Nilai & Prioritas \\
\hline 1 & Kurang Koordinasi & 0.217 & 2 \\
\hline 2 & Birokrasi buruk & 0.230 & 1 \\
\hline 3 & Kurang optimal pendapatan & 0.146 & 5 \\
\hline 4 & Realisasi Anggaran di AT & 0.214 & 3 \\
\hline 5 & Terbatasnya Insftratruktur & 0.192 & 4 \\
\hline
\end{tabular}

\subsection{Implikasi Kebijakan}

Pemerintah Provinsi Kalimantan Timur dengan seluruh komponen yang dimiliki sangat menyadari bahwa pelayanan publik merupakan unit sistem yang akan sangat menentukan rancang bangun perwujudan good gorvernance. Kesadaran ini memacu elemen instansi pemerintah daerah untuk menjadi penyelenggara pelayanan publik terbaik dengan terus melakukan sinergi dalam peningkatan pelayanan bagi kepentingan masyarakat luas. Perwujudan langkah yang harus dikembangkan adalah meningkatkan pemahaman dan keselarasan untuk menerapkan asas kepentingan umum, kepastian hukum, kesamaan hak, keseimbangan hak dan kewajiban, profesionalitas, partisipatif, persamaan perlakuan/ tidak diskriminatif, keterbukaan, akuntabilitas, fasilitas dan perlakuan khusus bagi kelompok rentan, ketepatan waktu, kecepatan, kemudahan, dan keterjangkauan wilayah.

Adapun para penyelenggara pelayanan publik di Kalimantan Timur telah mewujudkan inovasi berupa peningkatan pelayanan diberbagai layanan publik yang dapat menunjang peningkatan 
Pendapatan Asli Derah yang berupa : Penerapan Sistem Manajemen Mutu ISO 9001:2008 pada pelayanan Samsat Kota Balikpapan, Pelayanan BPKB Ditlantas Polda Kalimantan Timur, Pelaksanaan Ujian Teori Penerbitan SIM dengan sistem AVIS/DTMS, Pelayanan Gerai Samsat Corner di Mall Balikpapan, Trade Centre dan Mall Samarinda Centeral Plaza, Pembangunan tujuh Samsat Pembantu di wilayah Kalimantan Timur, Drive Thru Samsat Samarinda, SIM Corner di Samarinda Central Plaza.

Inovasi yang telah dilaksanakan tersebut diharapkan dapat meningkatkan PAD dalam mewujudkan kemandirian keuangan daerah serta memacu SKPD lainnya untuk selalu melakukan inovasi dalam pelayanananya kepada masyarakat. Inovasi pelayanan merupakan hal besar yang memerlukan usaha keras pemerintah karena adanya keterbatasan pendanaan dan sumber daya manusia dalam pengembangan teknologi di Indonesia. Daerah yang memiliki kemauan dan kemampuan untuk menciptakan sistem inovasi ini akan memiliki reputasi publik yang baik, sekaligus melakukan kerja nyata bagi penciptaan kinerja ekonomi. Berikut pada Tabel 14 ditampilkan perancangan program dan kegiatan yang sesuai dengan strategi yang terdapat pada hasil AHP.

Tabel 14. Perancangan Program dan Kegiatan Dalam Rangka Peningkatan Kinerja Keuangan Pemerintah Provinsi Kalimantan Timur Pasca Melemahnya Sektor Pertambangan Batubara

\begin{tabular}{|c|c|c|c|}
\hline Strategi & Program & Kegiatan & Pelaksana \\
\hline \multirow[t]{4}{*}{$\begin{array}{l}\text { Melakukan Inovasi } \\
\text { Pelayanan }\end{array}$} & \multirow{4}{*}{$\begin{array}{l}\text { Program } \\
\text { Pengembangan } \\
\text { Inovasi dan Sistem } \\
\text { Pelayanan }\end{array}$} & $\begin{array}{l}\text { 1. Penerapan Sistem Manajemen Mutu ISO 9001:2008 di seluruh } \\
\text { SAMSAT di Kalimantan Timur }\end{array}$ & \multirow{4}{*}{$\begin{array}{l}\text { Bapenda, BPKAD, } \\
\text { Ditlantas Polda } \\
\text { Kalimantan } \\
\text { Timur, Bappeda } \\
\text { Perusda, BLUD } \\
\text { BUMD \& BUMN, } \\
\text { Perbankan, } \\
\text { Kantor Pos, } \\
\text { minimarket, } \\
\text { PPOB }\end{array}$} \\
\hline & & $\begin{array}{l}\text { 2. Pengembangan profesionalisme dan menginternalisasikan nilai- } \\
\text { nilai service excellent pegawai SKPD/UPT/Perusda/ BLUD yang } \\
\text { berkaitan dengan PAD }\end{array}$ & \\
\hline & & $\begin{array}{l}\text { 3. Pengembangan Aplikasi web dan mobile untuk pembayaran } \\
\text { Pajak Kendaraan Bermotor dengan e-Samsat }\end{array}$ & \\
\hline & & $\begin{array}{l}\text { 4. Kerjasama dengan perbankan / Pos/ minimarket agar dapat } \\
\text { melakukan pembayaran pajak kendaraan bermotor via ATM / } \\
\text { Kantor Pos/Minimarket }\end{array}$ & \\
\hline \multirow{5}{*}{$\begin{array}{l}\text { Meningkatan } \\
\text { Kapasitas ASN }\end{array}$} & \multirow{5}{*}{$\begin{array}{l}\text { Program } \\
\text { Peningkatan } \\
\text { Kapasitas Aparatur }\end{array}$} & 1. $\quad$ Bimbingan Teknis Pengelola Keuangan OPD & \multirow{5}{*}{$\begin{array}{l}\text { BPKAD } \\
\text { BPSDM } \\
\text { BKD } \\
\text { SETDA } \\
\text { BALITBANGDA } \\
\text { UNIV ERSITAS } \\
\text { MULAWARMAN } \\
\text { DPRD }\end{array}$} \\
\hline & & $\begin{array}{l}\text { 2. Mengembangkan pola kompetisi, kompetensi dan assestment } \\
\text { center bagi ASN }\end{array}$ & \\
\hline & & $\begin{array}{l}\text { 3. Mengembangan pengelolaan sistem informasi SDM/HRIS } \\
\text { (Human Resources Information System) untuk Administrasi ASN, } \\
\text { Diklat, kinerja pegawai, dll. }\end{array}$ & \\
\hline & & 4. $\quad$ Kaderisasi /mentoring pegawai & \\
\hline & & $\begin{array}{l}\text { 5. Menciptakan budaya kerja \& nilai-nilai kearifan budaya lokal } \\
\text { sebagai pembentuk karakter ASN. “Gawi Manuntung Waja } \\
\text { Sampai Kaputing” Bekerja keras sampai tuntas, dengan } \\
\text { semangat baja hingga titik akhir. }\end{array}$ & \\
\hline \multirow{3}{*}{$\begin{array}{l}\text { Meningkatan } \\
\text { Komunikasi dan } \\
\text { Sinergi Keuangan } \\
\text { Daerah }\end{array}$} & \multirow{3}{*}{$\begin{array}{l}\text { Program } \\
\text { Peningkatan } \\
\text { Kejasama dan } \\
\text { Koordinasi } \\
\text { Keuangan Daerah }\end{array}$} & $\begin{array}{l}\text { 1. Membentuk forum tematik dengan para stakeholder (TAPD, } \\
\text { TEPRA, TPID, Bakohumas) }\end{array}$ & \multirow{3}{*}{$\begin{array}{l}\text { BPKAD, DPRD } \\
\text { KEMENKEU } \\
\text { DISKOMINFO } \\
\text { Biro HUMAS } \\
\text { Kpw BI } \\
\text { BPS, BULOG }\end{array}$} \\
\hline & & 2. Meningkatkan kerjasama informasi dengan media & \\
\hline & & $\begin{array}{l}\text { 3. Optimalisasi penggunaan media sosial untuk mendapatkan } \\
\text { masukan dari stakeholder (youtube, facebook, twitter, WA, dll). }\end{array}$ & \\
\hline \multirow{6}{*}{$\begin{array}{l}\text { Meningkatkan } \\
\text { Pengawasan }\end{array}$} & \multirow{6}{*}{$\begin{array}{l}\text { Program } \\
\text { Peningkatan } \\
\text { Sistem } \\
\text { Pengawasan }\end{array}$} & 1. Tindak lanjut hasil temuan pemeriksaan & \multirow{6}{*}{$\begin{array}{l}\text { Inspektorat } \\
\text { Kepolisian } \\
\text { Kejaksaan, DPRD } \\
\text { LSM, Kemenkeu, } \\
\text { Bank persepsi }\end{array}$} \\
\hline & & $\begin{array}{lll}\text { 2. } & \text { Koordinasi penyampaian } & \text { Laporan } \\
& \text { Penyelenggara Negara (LHKPN) }\end{array}$ & \\
\hline & & 3. $\quad$ Pengembangan whistleblowing system & \\
\hline & & $\begin{array}{ll}\text { 4. Membangun zona integritas (ZI) menuju Wilayah Bebas dari } \\
\text { Korupsi (WBK) dan Wilayah Birokrasi Bersih Melayani (WBBM) }\end{array}$ & \\
\hline & & 5. Peningkatan sinergi satgas SABER PUNGLI & \\
\hline & & $\begin{array}{l}\text { 6. Mengupayakan peningkatan pengawasan penerimaan dari Dana } \\
\text { Perimbangan, terutama yang bersumber dari dana bagi hasil } \\
\text { melalui kegiatan rekonsiliasi dan penelusuran bukti setor PNBP } \\
\text { (royalti) yang belum teridentifikasi }\end{array}$ & \\
\hline \multirow{3}{*}{$\begin{array}{l}\text { Menerapkan } \\
\text { Reward dan } \\
\text { Punishment }\end{array}$} & \multirow{3}{*}{$\begin{array}{l}\text { Program Monev } \\
\text { Penyerapan } \\
\text { Anggaran Daerah }\end{array}$} & 1. Pemberian penghargaan berupa piagam dan pelayanan prioritas & \multirow{3}{*}{$\begin{array}{l}\text { BPKAD, Setda } \\
\text { SKPD, } \\
\text { Diskominfo }\end{array}$} \\
\hline & & di BPKAD bagi SKPD yang mampu melakukan penyerapan & \\
\hline & & $\begin{array}{l}\text { 2. Pengembangan aplikasi berbasis web untuk memantau } \\
\text { penyerapan anggaran secara real time }\end{array}$ & \\
\hline
\end{tabular}




\section{KESIMPULAN DAN SARAN}

\subsection{Kesimpulan}

Berdasarkan hasil dan pembahasan yang telah disajikan sebelumnya, maka dapat disimpulkan bahwa ternyata harga energi batubara dan APBD berpengaruh positif dan nyata terhadap pertumbuhan ekonomi di Provinsi Kalimantan Timur, dikarenakan harga batubara sangat tergantung dengan harga komoditas batubara di dunia internasional dan sektor pertambangan merupakan sektor utama dalam PDRB Kalimantan Timur. Turunnya harga batubara ternyata mempengaruhi ekspor batubara Kalimantan Timur sehingga pertumbuhan ekonomi pun terkena dampak. Selain kinerja ekspor, pekerja di sektor pertambangan banyak yang kehilangan pekerjaan karena banyak perusahaan pertambangan mengurangi/merumahkan pekerjanya.

Kinerja keuangan Pemerintah Provinsi Kalimantan Timur tahun 2009 hingga 2016 menunjukkan kinerja yang baik, mandiri, dan cukup efektif. Melemahnya sektor pertambangan batubara akibat dari harga yang turun selain mengurangi jatah Dana Perimbangan melalui Dana Bagi Hasil SDA ternyata berdampak juga terhadap penurunan PAD. Peningkatan kinerja keuangan Pemprov Kalimantan Timur dapat tercapai apabila komponen PAD semakin meningkat kontribusinya dalam Pendapatan Daerah, sehingga Pemprov Kalimantan Timur tidak bergantung lagi dari Pemerintah Pusat melalui Dana Perimbangan. Otonomi daerah menuntut daerah yang mandiri dan mampu membiayai daerahnya tanpa terlalu tinggi tingkat ketergantungannya kepada Pemerintah Pusat. Dalam hubungan keuangan pusat dan daerah, memang tingkat ketergantungan daerah kepada pusat tidak dapat dihindarkan. Namun, setidaktidaknya ada upaya untuk mengurangi tingkat ketergantungan yang tinggi.

Strategi peningkatan kinerja keuangan Pemerintah Provinsi Kalimantan Timur terutama dalam hal peningkatan PAD berdasarkan hasil analisis AHP sesuai urutan prioritasnya yaitu: (1) inovasi pelayanan; (2) peningkatan kapasitas ASN; (3) peningkatan komunikasi; (4) peningkatan pengawasan; dan (5) penerapan reward dan punishment. Inovasi menjadi sesuatu yang mutlak dalam pelayanan publik karena apapun kebutuhan masyarakat, pemerintah harus merespon dengan cepat dan tepat. Inovasi juga diharapkan menjadi salah satu cara untuk mendorong percepatan pembangunan secara efektif dan efisien. Inovasi dimaksud bukan hanya berhubungan dengan teknologi dan informasi saja, tetapi juga inovasi dalam peningkatan kualitas SDM, pembuatan standar, serta kerjasama maupun benchmarking dengan institusi lain untuk memberikan perspektif yang berbeda.

\subsection{Saran}

Beberapa hal yang dapat disampaikan sebagai saran antara lain:

1. Bagi Pemerintah Provinsi Kalimantan Timur, diharapkan mampu meningkatkan kinerja keuangannya. Optimalisasi penerimaan daerah dari pajak dan retribusi harus terus dilakukan dan memberikan proporsi belanja modal yang lebih besar untuk pembangunan pada sektor sektor yang produktif non pertambangan di daerah.

2. Mengoptimalkan koordinasi antara Pemerintah Pusat, Pemerintah Provinsi, dan Kabupaten/Kota, serta meningkatkan upaya transfer knowledge kepada seluruh aparatur di Provinsi dan Kabupaten/Kota, terutama yang terkait dengan pengelolaan keuangan daerah.

3. Membangun kemitraan partisipatif dengan lintas perangkat daerah terkait, lembaga masyarakat, dunia usaha, dan perguruan tinggi dalam bidang perekonomian dan keuangan daerah sehingga tercipta kesejahteraan masyarakat di Provinsi Kalimantan Timur.

\section{IMPLIKASI DAN KETERBATASAN}

Penelitian ini memiliki keterbasan yang dapat dipertimbangkan dalam penelitian selanjutnya. Penelitian dilakukan hanya pada satu objek Pemerintah Provinsi Kalimantan timur tanpa memasukkan Kabupaten dan Kota di Kalimantan Timur, sehingga memungkinkan terjadinya perbedaan hasil penelitian apabila dilakukan pada objek penelitian lainnya. Oleh karena itu, pada penelitian selanjutnya direkomendasikan untuk memperbanyak objek penelitian tidak hanya pada satu objek, sehingga generalisasi hasil penelitian dapat lebih objektif.

\section{PENGHARGAAN}

Penulis menyadari sepenuhnya bahwa artikel ini tidak akan selesai tepat pada waktunya tanpa bantuan dari berbagai pihak. Oleh karena itu, penulis menyampaikan terima kasih dan penghargaan yang setinggi-tingginya kepada semua pihak yang telah memberikan bantuan bantuan selama penulisan ini berlangsung.

\section{DAFTAR PUSTAKA}

Andayani, W. 2004. Analisis Anggaran Pendapatan dan Belanja Daerah. Jurnal Akuntansi dan Keuangan Sektor Publik Vol 05, No 1 Februari. 
Falatehan, AF. 2016. Analytical Hierarchy Process (AHP): Teknik Pengambilan Keputusan untuk Pembangunan Daerah. Yogyakarta: Indomedia Pustaka.

Halim, A \& Kusufi, MS. 2012. Akuntansi Sektor Publik: Akuntansi Keuangan Daerah. Jakarta: Salemba Empat.

Halim, A. 2007. Akuntansi Sektor Publik: Akuntansi Keuangan Daerah. Jakarta: Salemba Empat.

Haryadi B. 2002. Analisis Pengaruh Fiscal Stress Terhadap Kinerja Keuangan Pemerintah Kabupaten/Kota Dalam Menghadapi Pelaksanaan Otonomi Daerah. Semarang: Simposium Nasional Akuntansi V.

Mahmudi. 2010. Analisis Laporan Keuangan Pemerintah Daerah. Yogyakarta: UPP STIM YKPN.

Mardiasmo. 2002. Otonomi dan Manajemen Keuangan Daerah. Yogyakarta: Andi.

OECD. 2011. Regulatory Policy and Governance: Supporting Economic Growth and Serving the Public Interest. OECD Publishing.

Todaro, MP. 1995. Ekonomi Untuk Negara Berkembang : Suatu Pengantar tentang Prinsip-Prinsip, Masalah dan Kebijakan Pembangunan, Terjemahan Agustinus Subekti. Jakarta: PT. Bumi Aksara.

Saaty, Thomas L. 1993. Pengambilan Keputusan Bagi Para Pemimpin. Jakarta: PT Pustaka Binaman Pressindo.

Sularso, Restianto. 2011. Pengaruh Kinerja Keuangan Terhadap Alokasi Belanja Modal dan Pertumbuhan Ekonomi Kabupaten/ Kota di Jawa Tengah. Purwokerto: Universitas Jendral Soedirman.

Susantih, H dan Saftiana, Y. 2009. Perbandingan Indikator Kinerja Keuangan Pemerintah Provinsi Se-Sumatra Bagian Selatan. Simposium Nasional Akuntansi 12. 
Lampiran 1

Tingkat Peranan Aktor Berdasarkan Faktor dalam Upaya Meningkatkan Kinerja Keuangan Pemerintah Provinsi Kalimantan Timur

\begin{tabular}{|c|c|c|c|c|}
\hline No & Faktor & Pelaku & Nilai & Prioritas \\
\hline \multirow[t]{5}{*}{1} & Perencanaan & Bappeda & 0.369 & 1 \\
\hline & & BPKAD & 0.098 & 5 \\
\hline & & Pemprov & 0.117 & 4 \\
\hline & & DPRD & 0.207 & 3 \\
\hline & & Pemerintah Pusat & 0.209 & 2 \\
\hline \multirow[t]{5}{*}{2} & SDM & Bappeda & 0.194 & 3 \\
\hline & & BPKAD & 0.201 & 2 \\
\hline & & Pemprov & 0.444 & 1 \\
\hline & & DPRD & 0.098 & 4 \\
\hline & & Pemerintah Pusat & 0.063 & 5 \\
\hline \multirow[t]{5}{*}{3} & Regulasi & Bappeda & 0.072 & 5 \\
\hline & & BPKAD & 0.351 & 1 \\
\hline & & Pemprov & 0.199 & 3 \\
\hline & & DPRD & 0.143 & 4 \\
\hline & & Pemerintah Pusat & 0.234 & 2 \\
\hline \multirow[t]{5}{*}{4} & $\begin{array}{l}\text { Dukungan } \\
\text { Kelembagaan }\end{array}$ & Bappeda & 0.115 & 5 \\
\hline & & BPKAD & 0.173 & 3 \\
\hline & & Pemprov/SKPD & 0.369 & 1 \\
\hline & & DPRD & 0.174 & 2 \\
\hline & & Pemerintah Pusat & 0.168 & 4 \\
\hline \multirow[t]{5}{*}{5} & Pengawasan & Bappeda & 0.08 & 5 \\
\hline & & BPKAD & 0.195 & 2 \\
\hline & & Pemprov/SKPD & 0.427 & 1 \\
\hline & & DPRD & 0.18 & 3 \\
\hline & & Pemerintah Pusat & 0.119 & 4 \\
\hline
\end{tabular}




\section{Lampiran 2}

Tingkat Peranan Kendala Berdasarkan Pelaku dalam Upaya Meningkatkan Kinerja Keuangan Pemerintah Provinsi Kalimantan Timur

\begin{tabular}{|c|l|l|c|c|}
\hline No & \multicolumn{1}{|c|}{ Pelaku } & \multicolumn{1}{c|}{ Kendala } & Nilai & Prioritas \\
\hline 1 & DPRD & Kurang Koordinasi & 0.314 & 1 \\
\hline & & Birokrasi buruk & 0.200 & 2 \\
\hline & & Kurang optimal pendapatan & 0.139 & 5 \\
\hline & & Realisasi Anggaran di AT & 0.178 & 3 \\
\hline & & Terbatasnya Insftratruktur & 0.168 & 4 \\
\hline 2 & Pemerintah Pusat (K/L) & Kurang Koordinasi & 0.181 & 3 \\
\hline & & Birokrasi buruk & 0.201 & 2 \\
\hline & & Kurang optimal pendapatan & 0.162 & 4 \\
\hline & & Realisasi Anggaran di AT & 0.297 & 1 \\
\hline & & Terbatasnya Insftratruktur & 0.159 & 5 \\
\hline 3 & Pemerintah Provinsi & Kurang Koordinasi & 0.145 & 5 \\
\hline & & Birokrasi buruk & 0.284 & 1 \\
\hline & & Kurang optimal pendapatan & 0.172 & 4 \\
\hline & & Realisasi Anggaran di AT & 0.220 & 2 \\
\hline & & Terbatasnya Insftratruktur & 0.179 & 3 \\
\hline 4 & DPRD & Kurang Koordinasi & 0.287 & 1 \\
\hline & & Birokrasi buruk & 0.230 & 2 \\
\hline & & Kurang optimal pendapatan & 0.117 & 5 \\
\hline & & Realisasi Anggaran di AT & 0.177 & 4 \\
\hline & & Terbatasnya Insftratruktur & 0.189 & 3 \\
\hline 5 & & Kurang Koordinasi & 0.252 & 2 \\
\hline & & Birokrasi buruk & 0.196 & 3 \\
\hline & & Kurang optimal pendapatan & 0.106 & 5 \\
\hline & & Realisasi Anggaran di AT & 0.152 & 4 \\
\hline & & Terbatasnya Insftratruktur & 0.293 & 1 \\
\hline & & & & \\
\hline & & & & \\
\hline & & & &
\end{tabular}




\section{Lampiran 3}

Tingkat Peranan Alternatif Strategi Berdasarkan Kendala dalam Upaya Meningkatkan Kinerja Keuangan Pemerintah provinsi Kalimantan Timur

\begin{tabular}{|c|l|l|c|c|}
\hline No & \multicolumn{1}{|c|}{ Kendala } & \multicolumn{1}{|c|}{ Alternatif Strategi } & Nilai & Prioritas \\
\hline 1 & Kurang koordinasi & Komunikasi & 0.303 & 1 \\
\hline & & Inovasi pelayanan & 0.221 & 2 \\
\hline & & Penerapan reward \& punishment & 0.202 & 3 \\
\hline & & Peningkatan kapasitas ASN & 0.147 & 4 \\
\hline & & Peningkatan Pengawasan & 0.127 & 5 \\
\hline 2 & Birokrasi buruk & Komunikasi & 0.269 & 1 \\
\hline & & Inovasi pelayanan & 0.230 & 2 \\
\hline & & Penerapan reward \& punishment & 0.163 & 4 \\
\hline & & Peningkatan kapasitas ASN & 0.208 & 3 \\
\hline 3 & $\begin{array}{l}\text { Kurang optimal } \\
\text { pendapatan }\end{array}$ & Peningkatan Pengawasan & 0.130 & 5 \\
\hline & & Komunikasi & 0.310 & 1 \\
\hline & & Inovasi pelayanan & 0.225 & 2 \\
\hline & & Penerapan reward \& punishment & 0.188 & 3 \\
\hline & & Peningkatan kapasitas ASN & 0.160 & 4 \\
\hline 4 & $\begin{array}{l}\text { Realisasi anggaran di } \\
\text { AT }\end{array}$ & Peningkatan Pengawasan & 0.118 & 5 \\
\hline & & Komunikasi & 0.230 & 2 \\
\hline & & Inovasi pelayanan & 0.237 & 1 \\
\hline & & Penerapan reward \& punishment & 0.265 & 3 \\
\hline & & Peningkatan kapasitas ASN & 0.146 & 4 \\
\hline 5 & $\begin{array}{l}\text { Terbatasnya } \\
\text { infrastruktur }\end{array}$ & Peningkatan Pengawasan & 0.122 & 5 \\
\hline & & Komunikasi & 0.222 & 2 \\
\hline & & Inovasi pelayanan & 0.208 & 3 \\
\hline & & Penerapan reward \& punishment & 0.303 & 1 \\
\hline & & Peningkatan kapasitas ASN & 0.140 & 4 \\
\hline
\end{tabular}




\section{Lampiran 4}

Tingkat Peranan Kendala dalam Faktor Berdasarkan Pelaku Dalam Upaya Meningkatkan Kinerja Keuangan Pemerintah Provinsi Kalimantan Timur

\begin{tabular}{|c|c|c|c|c|c|c|c|c|}
\hline No & Pelaku & Kendala & A & B & $\mathrm{C}$ & D & E & Nilai \\
\hline \multirow[t]{5}{*}{1} & Bappeda & Kurang Koordinasi & 0.528 & 0.371 & 0.332 & 0.182 & 0.155 & 0.314 \\
\hline & & Birokrasi buruk & 0.133 & 0.283 & 0.097 & 0.393 & 0.095 & 0.200 \\
\hline & & Kurang optimal pendapatan & 0.066 & 0.072 & 0.130 & 0.076 & 0.352 & 0.139 \\
\hline & & Realisasi Anggaran di AT & 0.120 & 0.118 & 0.161 & 0.180 & 0.311 & 0.178 \\
\hline & & Terbatasnya Insftratruktur & 0.153 & 0.155 & 0.279 & 0.169 & 0.086 & 0.168 \\
\hline \multirow[t]{5}{*}{2} & BPKAD & Kurang Koordinasi & 0.132 & 0.134 & 0.185 & 0.178 & 0.274 & 0.181 \\
\hline & & Birokrasi buruk & 0.135 & 0.186 & 0.292 & 0.282 & 0.111 & 0.201 \\
\hline & & Kurang optimal pendapatan & 0.269 & 0.163 & 0.085 & 0.098 & 0.193 & 0.162 \\
\hline & & Realisasi Anggaran di AT & 0.396 & 0.414 & 0.096 & 0.222 & 0.359 & 0.297 \\
\hline & & Terbatasnya Insftratruktur & 0.068 & 0.104 & 0.342 & 0.220 & 0.063 & 0.159 \\
\hline \multirow[t]{5}{*}{3} & Pemprov & Kurang Koordinasi & 0.127 & 0.072 & 0.103 & 0.259 & 0.162 & 0.145 \\
\hline & & Birokrasi buruk & 0.327 & 0.333 & 0.443 & 0.229 & 0.089 & 0.284 \\
\hline & & Kurang optimal pendapatan & 0.259 & 0.113 & 0.070 & 0.102 & 0.316 & 0.172 \\
\hline & & Realisasi Anggaran di AT & 0.193 & 0.163 & 0.191 & 0.252 & 0.303 & 0.220 \\
\hline & & Terbatasnya Insftratruktur & 0.095 & 0.319 & 0.192 & 0.157 & 0.130 & 0.179 \\
\hline \multirow[t]{5}{*}{4} & DPRD & Kurang Koordinasi & 0.403 & 0.123 & 0.383 & 0.359 & 0.166 & 0.287 \\
\hline & & Birokrasi buruk & 0.216 & 0.286 & 0.254 & 0.237 & 0.156 & 0.230 \\
\hline & & Kurang optimal pendapatan & 0.083 & 0.069 & 0.076 & 0.084 & 0.275 & 0.117 \\
\hline & & Realisasi Anggaran di AT & 0.186 & 0.109 & 0.128 & 0.129 & 0.333 & 0.177 \\
\hline & & Terbatasnya Insftratruktur & 0.113 & 0.413 & 0.159 & 0.191 & 0.071 & 0.189 \\
\hline \multirow[t]{5}{*}{5} & Pusat & Kurang Koordinasi & 0.214 & 0.191 & 0.408 & 0.321 & 0.125 & 0.252 \\
\hline & & Birokrasi buruk & 0.244 & 0.278 & 0.150 & 0.231 & 0.078 & 0.196 \\
\hline & & Kurang optimal pendapatan & 0.138 & 0.071 & 0.076 & 0.067 & 0.180 & 0.106 \\
\hline & & Realisasi Anggaran di AT & 0.079 & 0.110 & 0.221 & 0.111 & 0.239 & 0.152 \\
\hline & & Terbatasnya Insftratruktur & 0.325 & 0.350 & 0.144 & 0.270 & 0.377 & 0.293 \\
\hline
\end{tabular}

$\mathrm{A}=$ Faktor Perencanaan

$\mathrm{B}=$ Faktor SDM

$\mathrm{C}=$ Faktor Regulasi

$\mathrm{D}=$ Faktor Dukungan Kelembagaan

$\mathrm{E}=$ Faktor Pengawasan

Tingkat Peranan Pelaku Setelah Penilaian Pembobotan Dalam Upaya Meningkatkan Kinerja Keuangan Pemerintah Provinsi Kalimantan Timur

\begin{tabular}{|l|c|c|c|c|c|c|c|}
\hline Pelaku & RENC & SDM & REG & DLEMB & WAS & skor & Prioritas \\
\hline Bappeda & 0.369 & 0.194 & 0.072 & 0.115 & 0.08 & 0.157 & 3 \\
\hline BPKAD & 0.098 & 0.201 & 0.351 & 0.173 & 0.195 & 0.225 & 2 \\
\hline Pemprov & 0.117 & 0.444 & 0.199 & 0.369 & 0.427 & 0.311 & 1 \\
\hline DPRD & 0.207 & 0.098 & 0.143 & 0.174 & 0.18 & 0.150 & 5 \\
\hline Pusat & 0.209 & 0.063 & 0.234 & 0.168 & 0.119 & 0.157 & 4 \\
\hline bobot & 0.151 & 0.275 & 0.294 & 0.114 & 0.166 & 1.000 & \\
\hline
\end{tabular}




\section{Lampiran 5}

Tingkat Peranan Kendala setelah penilaian pembobotan Dalam Upaya Meningkatkan Kinerja Keuangan Pemerintah Provinsi Kalimantan Timur

\begin{tabular}{|l|r|r|r|r|r|c|c|}
\hline Kendala & \multicolumn{1}{|c|}{ Bappeda } & \multicolumn{1}{c|}{ BPKAD } & Pemprov & \multicolumn{1}{c|}{ DPRD } & Pempus & skor & Prioritas \\
\hline Kurang Koordinasi & 0.314 & 0.181 & 0.145 & 0.287 & 0.252 & 0.217 & 2 \\
\hline Birokrasi buruk & 0.200 & 0.201 & 0.284 & 0.230 & 0.196 & 0.230 & 1 \\
\hline Kurang optimal pendapatan & 0.139 & 0.162 & 0.172 & 0.117 & 0.106 & 0.146 & 5 \\
\hline Realisasi Anggaran di AT & 0.178 & 0.297 & 0.220 & 0.177 & 0.152 & 0.214 & 3 \\
\hline Terbatasnya Insftratruktur & 0.168 & 0.159 & 0.179 & 0.189 & 0.293 & 0.192 & 4 \\
\hline bobot & 0.157 & 0.225 & 0.311 & 0.150 & 0.157 & 1.000 & \\
\hline
\end{tabular}

Hasil Perumusan Strategi Peningkatan Kinerja Keuangan Pemerintah Provinsi Kalimantan Timur Berdasarkan AHP Menggunakan Expert Choice 11

\begin{tabular}{|l|c|c|}
\hline \multicolumn{1}{|c|}{ Strategi } & Nilai AHP & Prioritas \\
\hline Komunikasi & .188 & 3 \\
\hline Inovasi Pelayanan & .268 & 1 \\
\hline Penerapan Reward Punishment & .144 & 5 \\
\hline Peningkatan Kapasitas ASN & .236 & 2 \\
\hline Tingkatan Pengawasan & .164 & 4 \\
\hline
\end{tabular}

